\title{
FOR TEACHERS OF CANADIAN CONTENT
}

Do you incorporate Canadian content in your adult ESL classes? Do you teach a citizenship preparation course to adult immigrants? Secretary of State, in conjunction with Sidney Pratt, a leading citizenship educator in Canada, and Language Assessment \& Research Consultants (Edmonton), is conducting a survey of all adult citizenship education programs across the country. At the same time, citizenship materials will be collected which will service as the basis for an annotated bibliography that will help teachers in their selection of suitable materials. The suggestions of program coordinators and teachers will be used in the development of guidelines for a national curriculum.

The major obstacle in conducting research of this kind is in identifying programs involved in adult immigrant education - either citizenship preparation for the court interview or a more general approach to participatory citizenship in settlement or ESL classes. If you are aware of an ESL or immigrant aid program in which students learn about Canada and what is means to be Canadian, than we want to hear from you! Let us know what your concerns are, and help us share our findings with you.

Please contact

Murray Munro or Tracey Derwing

Language Assessment \& Research Consultants

10942 - 88 Avenue

Edmonton, Alberta

T6G 0Z1 